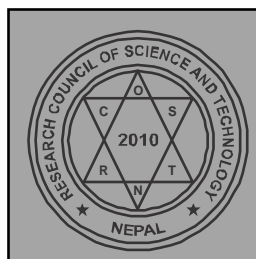

\title{
BIBECHANA
}

A Multidisciplinary Journal of Science, Technology and Mathematics

ISSN 2091-0762 (online)

Journal homepage: http://nepjol.info/index.php/BIBECHANA

\section{Study of critical micelle concentration of cetyltrimethylammonium bromide (CTAB) in pure water in presence and absence of magnesium sulphate and sodium sulphate by measuring conductivity meter}

\author{
Ajaya Bhattarai*, Ghanashyam Shrivastav, Chom Nath Adhikari \\ Department of Chemistry, M.M.A.M. C., Tribhuvan University, Biratnagar, Nepal \\ *Corresponding author: E-mail: bkajaya@yahoo.com
}

Accepted for publication: February 18, 2014

\begin{abstract}
The precise measurement of specific conductivity of cetyltrimethylammonium bromide (CTAB) in distilled water at room temperature was reported and also the specific conductivity of cetyltrimethylammonium bromide was measured in the presence of magnesium sulphate and sodium sulphate using a conductivity meter. The critical micelle concentration of three systems was calculated. The comparison of $\mathrm{cmc}$ among them was also performed.
\end{abstract}

(C) 2014 RCOST: All rights reserved.

Keywords: Conductivity meter; Cetyltrimethylammonium bromide; Specific conductivity; Critical micelle concentration; Sodium sulphate; Magnesium sulphate.

\section{Introduction}

Cetyltrimethylammonium bromide (CTAB) is a highly effective cationic surfactant in daily life. CTAB type of compound is found in high concentration in industrial products like detergents industries. The charge on the head group of CTAB is positive that is why the surfactant is said to be cationic surfactants. Due to the positive charge of the head group, cationic surfactants strongly adsorb on the negatively charged surfaces such as fabric, hair and cell membrane of bacteria. Therefore they are used as a fabric softeners, hair conditioners and antibacterial agents.

The IUPAC name of cetyltrimethylammoniumbromide is hexadecyltrimethylammonium bromide having molecular weight 364.45 and it has structure in Fig.1. The effect of inorganic salt is explained in terms of the shielding of the electrostatic repulsion by the counterions [1]. Chung et al.[1,2] studied the effect of $\mathrm{KCl}$ and alcohol on the cmc of cetylpyridinium Chloride (CPC). They observed the decrease in cmc with the addition of electrolyte and vice versa.

In this paper, we report a study of the aggregation process of CTAB at room temperature in absence and in presence of Sodium sulphate and Magnesium sulphate by conductivity method in aqueous media.

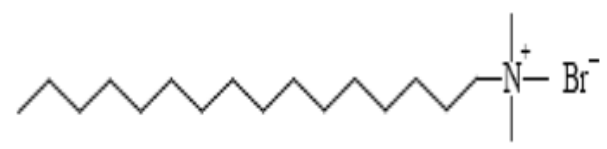

Figure 1: Cetyltrimethylammonium bromide 
A. Bhattarai et al. / BIBECHANA 11(1) (2014) 123-127: (Online Publication: March, 2014) p.124

\section{Experimental Section}

Conductance measurements were carried out on a Pye-Unicam PW 9509 conductivity meter at a frequency of $2000 \mathrm{~Hz}$ using a dip-type cell with a cell constant of $1.15 \mathrm{~cm}^{-1}$ and having an uncertainty of $0.01 \%$. The cell was calibrated by the method of Lind and co-workers [3] using aqueous potassium chloride solution. Several independent solutions were prepared and runs were performed to ensure the reproducibility of the results. Due correction was made for the specific conductance of the solvent by subtracting the specific conductance of the relevant solvent medium from those of the surfactant solutions.

Cetyltrimethylammonium bromide (CTAB) was purchased from Loba Chemical, India. $\mathrm{MgSO}_{4}$ and $\mathrm{Na}_{2} \mathrm{SO}_{4}$ were purchased from Ranbaxy Chemical, India. The water used in the experiments was doubly distilled. The solutions prepared at room temperature.

\section{Results and Discussion}

The specific conductivities of CTAB solution increase with increasing the concentration of CTAB. There is sharp break in which two straight lines intersect. That point of intersection is known as critical micelle concentration $(\mathrm{cmc})$. The electrical conductivity of a cationic surfactant certltrimethylammonium bromide in distilled water was reported (Table 1).

The sodium ion $\left(\mathrm{Na}^{+}\right)$is larger than the magnesium ion $\left(\mathrm{Mg}^{2+}\right)$ due to two effects. The elements sodium and magnesium are in the same Period, therefore outer electrons of the $\mathrm{Mg}$ atom experience greater effective nuclear charge and, more importantly, the magnesium cation, $\mathrm{Mg}^{2+}$, has a greater cationic charge than the $\mathrm{Na}^{+}$cation. This second effect is by far the more significant. The conductivities of CTAB in presence of $\mathrm{Na}_{2} \mathrm{SO}_{4}$ is more than in presence of $\mathrm{MgSO}_{4}$ because the smaller ions are strongly hydrated, so they need to pull more water molecules with them which makes them less mobile. Hence the conductivity values of CTAB in presence of $\mathrm{Na}_{2} \mathrm{SO}_{4}$ are high in comparison with $\mathrm{MgSO}_{4}$ as shown in Table 1 (A\&B).

In water, the $c m c s$ of CTAB were reported [4] to be $1.007 \mathrm{mM}$ from conductometry, and $1.102 \mathrm{mM}$ from tensiometry respectively at $308.15 \mathrm{~K}$ which verifies our experimental data of cmc of CTAB at room temperature (Table 2). Figures (2-4) show the cmc of CTAB in absence and in presence of $\mathrm{Na}_{2} \mathrm{SO}_{4}$ and $\mathrm{MgSO}_{4}$. Also, the cmc values of CTAB in absence and presence of $\mathrm{Na}_{2} \mathrm{SO}_{4}$ and $\mathrm{MgSO}_{4}$ at room temperature are shown in Table 2. As the salt is added, the electrostatic repulsive force between ionic head groups of the surfactant molecules is reduced by shielding of micelle charge, so that spherical micelles are more closely packed by the surfactant ions [5,6], hence a decrease in the cmc values after adding salts. It is observed that salts decrease the cmc of ionic surfactants [7] due to screening of the electrostatic repulsion among the polar head groups and movement of the hydrophobic alkyl chain away from aqueous environment, so that less electrical work is required to form micelles.

Salts decrease the cmc in the order: $\mathrm{MgSO}_{4}<\mathrm{Na}_{2} \mathrm{SO}_{4}$. Here $\mathrm{Mg}^{++}$is least effective in decreasing the $\mathrm{cmc}$ due to small size and large hydrated radius and would act as a water-structure promoter decreasing the availability of water to the micelles. Therefore, upon addition of $\mathrm{MgSO}_{4}$ and $\mathrm{Na}_{2} \mathrm{SO}_{4}$ in $\mathrm{CTAB}, \mathrm{Na}_{2} \mathrm{SO}_{4}$ is more effective in reducing the cmc of CTAB. Hence in our case $\mathrm{Na}_{2} \mathrm{SO}_{4}$ decreases the cmc of CTAB more than $\mathrm{MgSO}_{4}$ (Table 2). 
A. Bhattarai et al. / BIBECHANA 11(1) (2014) 123-127: (Online Publication: March, 2014) p.125

Table 1: Conductance of CTAB in distilled water at room temperature.

\begin{tabular}{|c|c|c|}
\hline Solvent & Concentration $(\mathrm{mol} / \mathrm{ltr})$ & Conductance $\left(\mathrm{ohm}^{-1} \mathrm{~cm}^{-1}\right)$ \\
\hline & 0.00436 & 0.283 \\
0.00313 & 0.251 \\
0.00224 & 0.226 \\
0.00161 & 0.205 \\
Distilled & 0.00115 & 0.185 \\
Water & 0.00083 & 0.174 \\
& 0.00059 & 0.160 \\
& 0.00042 & 0.151 \\
& 0.00030 & 0.142 \\
& 0.00022 & 0.136 \\
& 0.00015 & 0.128 \\
& 0.00011 & 0.121 \\
\hline
\end{tabular}

Table 1A: Conductance of CTAB in presence of $\mathrm{Na}_{2} \mathrm{SO}_{4}$-Water at room temperature.

\begin{tabular}{|l|c|c|}
\hline Solvent & Concentration $(\mathrm{mol} / \mathrm{ltr})$ & Conductance $\left(\mathrm{ohm}^{-1} \mathrm{~cm}^{-1}\right)$ \\
\hline & 0.00600 & 1.820 \\
0.00503 & 1.812 \\
& 0.00410 & 1.805 \\
$\mathrm{Na}_{2} \mathrm{SO}_{4}$-Water & 0.00310 & 1.790 \\
& 0.00262 & 1.793 \\
& 0.00210 & 1.789 \\
& 0.00169 & 1.786 \\
& 0.00136 & 1.783 \\
& 0.00108 & 1.781 \\
& 0.00088 & 1.779 \\
& 0.00068 & 1.778 \\
& 0.00055 & 1.777 \\
& 0.00044 & 1.776 \\
& 0.00035 & 1.771 \\
& 0.00028 & 1.768 \\
& 0.00018 & 1.764 \\
\hline
\end{tabular}


A. Bhattarai et al. / BIBECHANA 11(1) (2014) 123-127: (Online Publication: March, 2014) p.126

Table 1B: Conductance of CTAB in presence of $\mathrm{MgSO}_{4}-$ Water at room temperature.

\begin{tabular}{|l|c|c|}
\hline Solvent & Concentration $(\mathrm{mol} / \mathrm{ltr})$ & Conductance $\left(\mathrm{ohm}^{-1} \mathrm{~cm}^{-1}\right)$ \\
\hline & 0.00671 & 1.867 \\
& 0.00537 & 1.829 \\
$\mathrm{MgSO}_{4}$-Water & 0.00429 & 1.790 \\
& 0.00343 & 1.758 \\
& 0.00275 & 1.739 \\
& 0.00171 & 1.704 \\
& 0.00140 & 1.691 \\
& 0.00112 & 1.684 \\
& 0.00091 & 1.677 \\
& 0.00075 & 1.672 \\
& 0.00057 & 1.661 \\
& 0.00046 & 1.651 \\
& 0.00036 & 1.646 \\
\hline
\end{tabular}

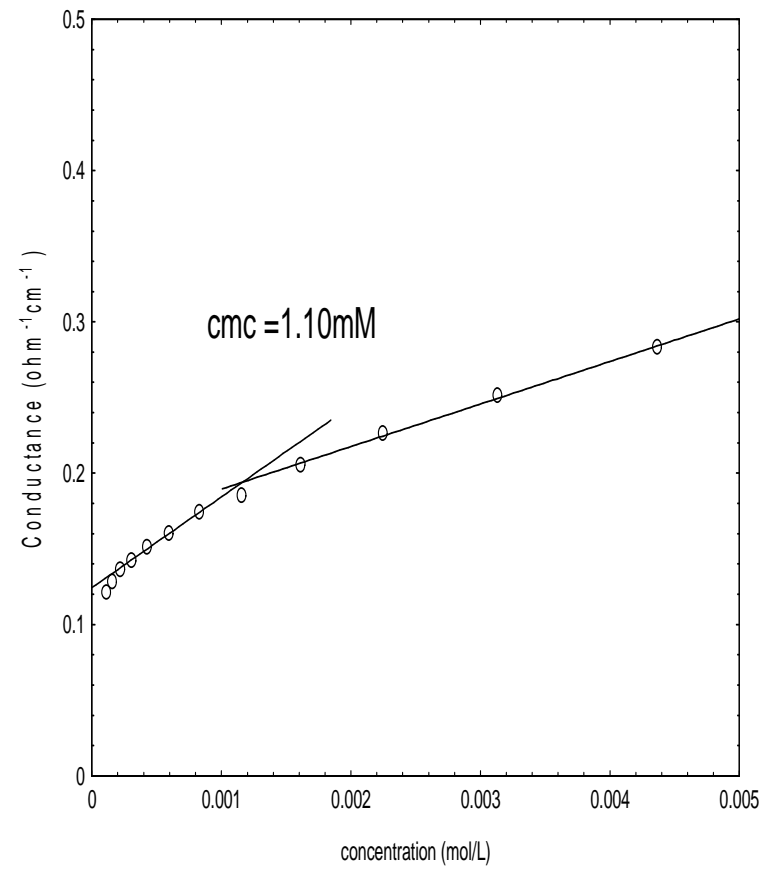

Fig. 2

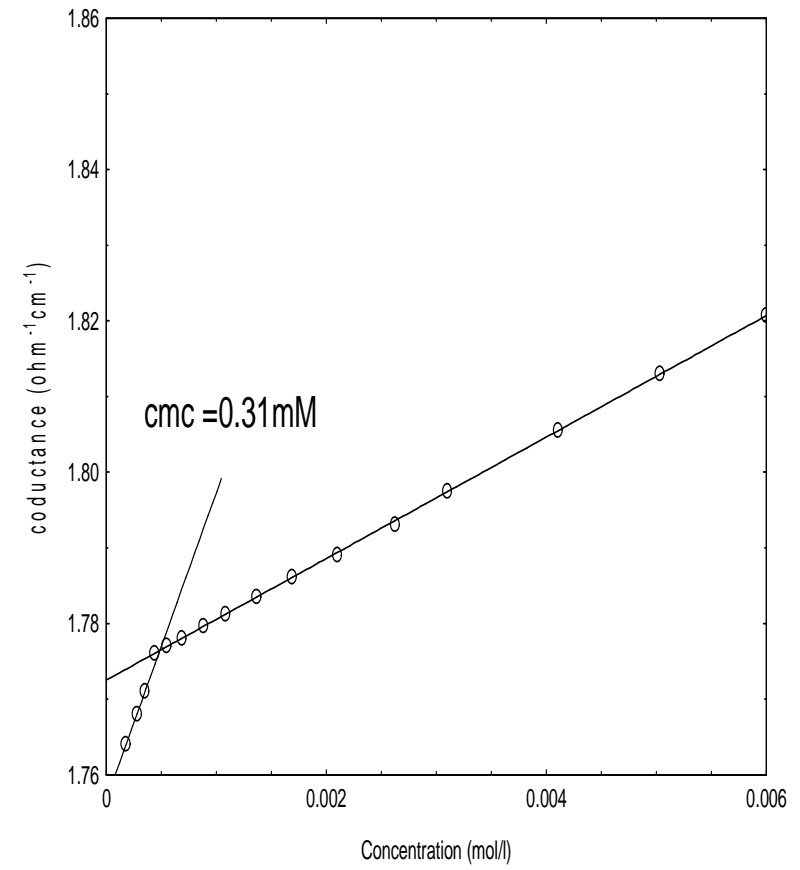

Fig.3

Figure 2: Specific conductivities of $\mathrm{CTAB}$ as a function of the concentration in distilled water at room temperature. Figure 3: Specific conductivities of CTAB as a function of the concentration in $\mathrm{Na}_{2} \mathrm{SO}_{4}$-water at room temperature. 
A. Bhattarai et al. / BIBECHANA 11(1) (2014) 123-127: (Online Publication: March, 2014) p.127

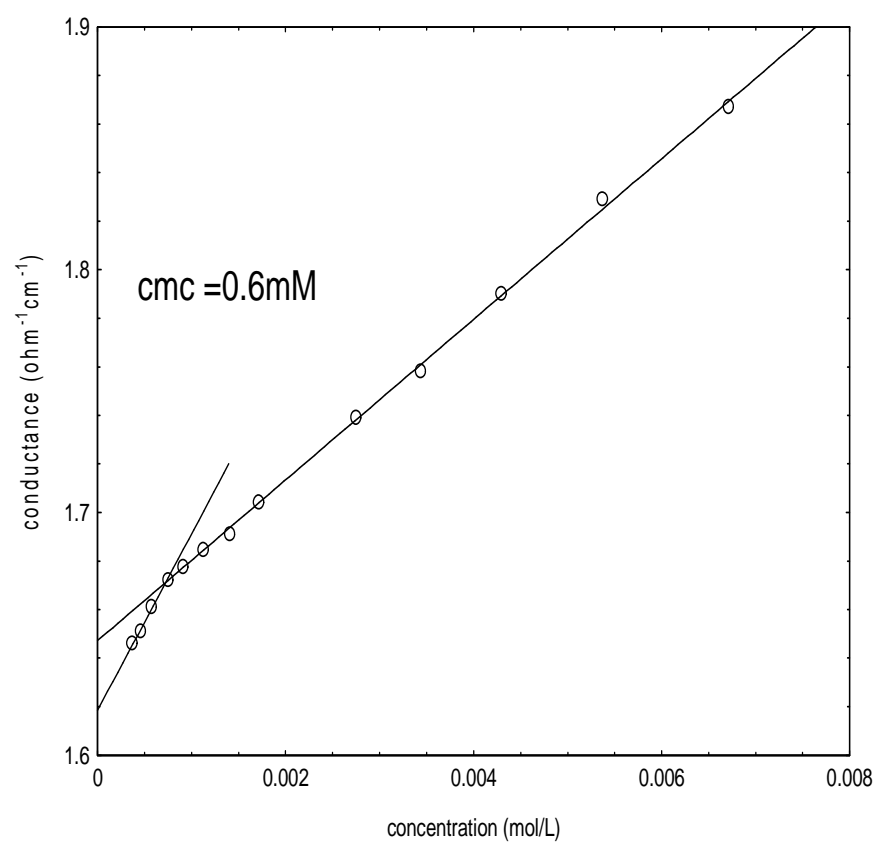

Figure 4: Specific conductivities of CTAB as a function of the concentration in $\mathrm{MgSO}_{4}$-Water at room temperature.

Table 2: Critical micelle concentration $(\mathrm{cmc})$ obtained from conductometry of CTAB in absence and presence of $\mathrm{Na}_{2} \mathrm{SO}_{4}$ and $\mathrm{MgSO}_{4}$ in aqueous media at room temperature.

\begin{tabular}{|c|c|c|}
\hline $\begin{array}{c}\text { Distilled water } \\
\mathrm{cmc}(\mathrm{mM})\end{array}$ & $\begin{array}{c}\mathrm{Na}_{2} \mathrm{SO}_{4} \text {-Water } \\
\mathrm{cmc}(\mathrm{mM})\end{array}$ & $\begin{array}{c}\mathrm{MgSO}_{4} \text {-Water } \\
\mathrm{cmc}(\mathrm{mM})\end{array}$ \\
\hline 1.10 & 0.31 & 0.63 \\
\hline
\end{tabular}

\section{Conclusion}

The following conclusions have been drawn from above result and discussions. The results showed an increase in conductivity of cetyltrimethylammonium bromide with addition of salts. The conductance of cetyltrimethylammonium bromide is found more in presence of $\mathrm{Na}_{2} \mathrm{SO}_{4}$ than $\mathrm{MgSO}_{4}$ in aqueous media whereas in the presence of $\mathrm{Na}_{2} \mathrm{SO}_{4}$, the cmc of cetyltrimethylammonium bromide decreases more in comparison with presence of $\mathrm{MgSO}_{4}$.

\section{References}

[1] J. J. Chung, S. W. Lee, J. H. Choi, Bull. Kor. Chem. Soc., 12 (1991) 411.

[2] J. J. Chung, S. W. Lee, Y. C. Kim, Bull. Kor. Chem. Soc., 13 (1992) 647.

[3] J. E. Jr. Lind, J. J. Zwolenik, R. M. Fuoss, J. Am. Chem. Soc., 81 (1959) 1557.

[4] T. Chakraborty, I. Chakraborty, S. Ghosh, Langmuir, 22 (2006) 9905.

[5] D.Varade, T. Joshi, V.K. Aswal, P. S. Goyal, P.A. Hassan, P. Bahadur, Colloids and Surfaces A: Physicochem. Eng. Aspects, 25 (2005) 95.

[6] H.N.Singh, S. Swarup, S.M. Saleem, J. Colloid and Interface. Sci., 68 (1979) 128.

[7] L. Zang, P. Somasundaran, C. Maltesh, Langmuir, 12 (1996) 2371. 